História (São Paulo)

\title{
The signature of the city: abandonment and dreaming in colonial Williamsburg and Ottawa
}

\section{A assinatura da cidade: abandono e sonho nas cidades coloniais de Williamsburg e Ottawa}

Mark KRISTMANSON*

\begin{abstract}
Exploring the themes of abandonment and dreaming in relation to two North American capital cities, this interdisciplinary narrative essay examines the Canadian Prime Minister William Lyon Mackenzie King's influence on the planning and architecture of Ottawa in relation to his frequent visits to Colonial Williamsburg, the restored former capital of Virginia. At the invitation of John D. Rockefeller Jr., King became a regular guest in Williamsburg during the 1930s and 1940s culminating in the conferral of an honorary degree by the College of William and Mary in 1948. The records of these visits provide a diagnostic used to conceptualize the 'signature' of the capital city. In abandonment and in dreaming, capital cities are especially exposed to latent forces of nature and of 'museumification'. These two forces created a tension that complicated attempts by King and Rockefeller to leave permanent architectural legacies in the signatures of their respective capitals.
\end{abstract}

Keywords: Mackenzie King. Williamsburg. Ottawa.

Resumo: Ao explorar temas do abandono e do sonho em relação a duas cidades capitais da parte norte do continente Americano, este ensaio narrativo, de caráter interdisciplinar, examina a influência do primeiro ministro William Lyon Mankenzie King no planejamento e na arquitetura de Ottawa, a partir de suas frequentes visitas à Williamsburg, capital colonial da Virginia. A partir do convite de John D. Rockefeller Jr., o ministro King visitou inúmeras vezes Williamsburg, durante os anos 1930 e 1940, e

* Dr. Mark Kristmanson is the 2011 Canada-US Fulbright Visiting Chair in Public Diplomacy at the USC Centre on Public Diplomacy, Annenberg School, University of Southern California in Los Angeles. He is the Director of Public Programming for the National Capital Commission, Ottawa, Canada. Email: mdk_626@usc.edu or mark.kristmanson@nccccn.ca lmdk@kristmanson.com 
foi condecorado pelo College of William and Mary, em 1948. Os registros destas viagens possibilitam um diagnóstico para conceitualizar a "assinatura” de uma cidade capital. No abandono e no sonho, as cidades capitais são especialmente expostas às forças latentes da natureza e da "museificação". Essa duas forças criaram tensões para as complexas tentativas de King e Rockfeller de deixar legados arquitetônicos permanentes na assinatura de suas respectivas capitais.

Palavras-chave: Mackenzie King. Williamsburg. Ottawa.

The state of nature is not a real epoch chronologically prior to the foundation of the City but a principle internal to the City, which appears at the moment the City is considered tanquam dissoluta, "as if it were dissolved."

Giorgio Agamben, Homo Sacer

We know...that vivid structures find their way into our dreams at night and it is here - in the dreamworld - that the visions of the architect and the dreams of the citizen find curious communion. Christopher Bollas, The Evocative Object World

In the summer of 1947 Canada’s Prime Minister, William Lyon Mackenzie King, received an emissary from Colonial Williamsburg in Virginia who came to Ottawa proposing honorary degrees from the College of William and Mary. King made no immediate answer but he found it appealing that these distinctions were to be conferred simultaneously upon himself and Canada's Governor General Viscount Alexander in the presence of U.S. President Harry S. Truman. By then nearing the end of his career as Canada's longest serving Prime Minister, he seized the opportunity to discuss other topics relevant to securing his place in Canadian public memory with his American visitor, Kenneth Chorley, an executive of Colonial Williamsburg who would shortly become its president. Devoted to commemorating America's founding statesmen through the restoration and animation of the colonialera Virginian capital, Chorley was an ideal interlocutor with whom King could speak frankly about leaving his stamp on the architecture, planning and commemorations of the Canadian capital:

We drove past the War Memorial and the Chateau. Came around by Major Hill Park and back to [Laurier House] via Elgin St., so as to show Chorley the developments that had taken place there. It only occurred to me as we were going along that he had had to do with the restoration of a Capital as it was, and I was showing him the making of a 
The Signature of the City: Abandonment and Dreaming in Colonial Williamsburg and Ottawa

Capital along lines that would be worthy of the future. I confess to having felt a sense of amazement and pride as to the number of things it was possible to point to, which were done in the first place at my own instance: the widening of Elgin Street; taking out buildings where the monument was on the square; placing the monument there; Research buildings, other buildings. Driveways, etc. Something indeed to be proud of ${ }^{1}$ (WLKM, 1947).

The two men discussed the master plan for the Canadian capital city and King's ambitions for its long-term development. This was King's “favourite subject” and, despite his foibles (e.g. antimodernism, fondness for ruins, spiritualist influences), it was an area where his wide-ranging travels and long political experience granted him self-assurance ${ }^{2}$. With Williamsburg in mind, he focused discussions with Chorley on how his two properties, the downtown Laurier House and his country property at Kingsmere, might be deeded to the state and maintained as heritage museums.

This narrative essay traces a conceptual outline for the 'signature' of the capital city. Taking the cases of Williamsburg and Ottawa as North American capitals, as seen through the lens of Mackenzie King, I will proceed by articulating the two themes of the present collection, abandonment and dreaming, in relation to the underlying presence of nature and commemorative layers of built heritage.

Directing historical inquiry of capital cities towards the entire sweep of the Americas from the southern cone to the Arctic wilderness has the salutary effect of bringing the entire European colonial project into one pan-hemispheric frame of analysis. Although this essay merely genuflects to the longer colonial and national histories of Latin America reflected in other contributions to this volume, it is significant to the subject at hand that a capital city such as Lima, for example, pre-dates northern counterparts such as Washington by more than two hundred and fifty years and Ottawa by more than three hundred years. It remains inscribed in their built signatures that Latin American capitals founded in the Baroque era are distinct from Washington's neo-classical birth moment or Ottawa's neo-Gothic distillation of nineteenth-century romanticism. To some extent these original cultural frames persist as architectural vestiges of the ancien régime or emergent modernity in Europe. Perhaps no other capital reflects its founding era so purely as does Williamsburg, Virginia.

For this reason and others discussed below, Williamsburg is a paradigm for the study of abandoned capitals. Poised at a mid-point in the long arc of European imperial expansion it is a rare instance of a North American capital city abandoned in its maturity. Yet, paradoxically, it was not truly abandoned. As a result of its centrality in the events of the American Revolution it enjoys a robust afterlife as the world's largest living history museum and, despite a broad interpretive shift towards social history in recent decades, remains dedicated to capturing America’s transition from colony and 
nation. As a form of ghost capital, it stands as a restored and sanitized artifact of colonial-era cultural heritage wherein the absence of the sovereign power of the state is transformed into a purely symbolic power of the capital-as-museum.

The intersection of abandonment and dreaming, the two axes proposed by Laurent Vidal for the present collection of studies of capital cities, brings the 'sovereign power' that grants a capital city its singular status into direct relation with the collective unconscious of its citizens. At this juncture of power, space, memory and imagination, certain questions form: What historical legacies does sovereign power vest in the built situation of its 'seat' in the capital city? What does the 'dreamt' or unconscious capital, utopian or otherwise, say about the exercise of sovereign power in a democratic state? What latencies are associated with a capital city’s potential abandonment? What do abandonment and dreaming reveal about the 'signature' of a capital city?

To approach such questions, the capital city is understood here as an evocative object whose unique character or signature presents a palimpsest of action that absorbs people's collective and intergenerational experiences. Architect Renzo Piano speaks of this collective sedimentation of meaning:

A city is 'slow' by definition, growing in homeopathic doses and not in a surgical way; its physiological time is long. A city is not planned: it performs this in itself. It is a matter of listening to it: the city reflects its many histories (PIANO, 2007, p.87-88, My translation).

Like other forms of the city, capital cities form slow signatures that are richly evocative, in some cases with built patrimonial layers accrued over centuries or even millennia ${ }^{3}$. Unique to national capital cities is their monumental function with respect to the state. Despite constantly emitting of minute-to-minute information in the highly charged operations of government, ultimately national capitals are a genre of knowledge vested in an architectural agglomeration that acts in the manner of a national 'monument'.

I suggest that the capital city holds in check at least two latent processes that will emerge in the case of its abandonment. The first is the suppressed 'state of nature' that will reassert itself, albeit gradually and subtly, when the sovereign power shifts away from the capital city leaving behind the mere city. The second - and this varies depending on the history of the capital in question - is a crystallization of the commemorative and 'museal' layer vested in its built environment and written into the national history. 
The Signature of the City: Abandonment and Dreaming in Colonial Williamsburg and Ottawa

Once made manifest, these two latencies may form a communion in a former capital's decay into ruin. If the heritage layer is weak in relation to the state of nature, then the abandoned capital may eventually disappear altogether as was the case when the colonial-era capital of Maryland, St. Mary's, disappeared entirely after being abandoned in favor of Annapolis. ${ }^{4}$ In an inverse case where the residual symbolic relevance (i.e. it's heritage value) of the abandoned capital is strong, such as Williamsburg, then a tension remains between the state of nature and the persistence of the capital as a specific type of museum.

Either way, an interruption in the intended permanence and performance of a capital city through its abandonment introduces a profound rupture and revision in its evocative suggestiveness as an object of knowledge. In this moment of rupture, when the abandoned capital is no longer a symbol of sovereign power, and no longer needs to appear or act as such, such latencies emerge as new forces to alter the signature of the city.

\section{Dreaming}

The 'dreamt capital' may, as in the case of Mackenzie King, express a wish for immortality or, at least, a wish not to be forgotten. Anticipating the future evocations of a capital city, a statesman's dreamt architecture can thus be associated with the latent process I call 'museumification' whereby living architecture of a capital city, and not just its museums, preponderantly assumes a commemorative function. In his exploration architecture's relation to the unconscious, Christopher Bollas observes that two well-known art museums, Piano's Beaubourg and Gehry's Guggenheim Museum in Bilbao are more than mere buildings. Rather, they are "testimonies to our vision of the future" that will "signify us in the future, giving us a place in historical time and the existential reality of future generations who, upon gazing at these objects, may think of our era.” (BOLLAS, 2009, p.50$51)$.

The same can be said for the master plan of a capital city that becomes, as L'Enfant's vision did for Washington, or Costa's and Niemeyer's for Brazilia, iconic in itself. ${ }^{5}$ The French planner Jacques Gréber, tasked with realizing Mackenzie King's dreamt capital, introduced the most influential of the master plans for Canada's National Capital Region in 1949 emphasizing that: “a capital city is the symbol of the life and progress of a nation, the permanent witness of its history."6 (GRÉBER, 1949, p.401). 
The intended permanence of King's capital city positions it exactly in Bollas's ambiguity of human finitude whereby monumental structures will "be dreamt upon [and] extend themselves into our dreams and those of the generations to come." It is the "uncanny compromise achieved by the monumental," he says, that makes the grand public architecture of a city "both a sign of life and a sign of death.” (BOLLAS, 2009, p.65). Thus, to dream "is to take our entire history with us into the darkness.” There, in our subconscious visual imagination, “vivid architecture” emerges. Both in the dream and in the waking world, architecture is redolent with some degree of evocative suggestiveness, and it is this "reverberance," as he calls it, that seems "to transcend the terminability of us and our works and stimulate[s] the imagination as we walk about in the shadows of death.” (Ibid., p.63-64).

The concern of a powerful figure such as a Prime Minister or an industrial tycoon that he or she eventually will be forgotten is a not-so-secret worry intuitively understood by everyone. It forms part of an unconscious-to-unconscious exchange between any given regime and its subjects who also, to some extent, may identify themselves with the leadership’s legacy. Yet there seems to be a more intricate commemorative pirouette indicated here. As Mackenzie King accelerated the development of Ottawa and Hull as a capital region in 1927 he put it in these terms to the Canadian Parliament:

As we look upon the countries of the past and the countries of the present, we find more and more reason to attach great significance to the proper development of our capital. When we think of ancient Greece we think of Athens and all that Athens stood for, and we judge the character of the ancient Greeks largely...by way of the remnants of architecture in that city. (HOUSE OF COMMONS, 1928, p.2320-2321).

Here the dreamt capital's intended permanence is partially disavowed by King in favor of a grandeur heightened by its being destined from the outset to become a ruin, still evoking 'us' (perhaps mainly via 'him') but even more distantly and thus more evocatively in the hazy gloss of nostalgia.

In Heztler's elegant definition, the ruin is "the disjunctive product of the intrusion of nature without the loss of unity that man produced." (HEZTLER, 1982, p.105-108). Arguably, this formulation is incomplete inasmuch as it too radically opposes man and nature, but it suggests a useful notion of degrees of loss in meaning of man-made structures. This establishes a scale whereby a perfectly nostalgic ruin would evoke man's unity but in the softest possible historical focus. The dreamt capital, fast-forwarded to its eventual ruin, elides the densely complex and vexed social and political realities of its lived historical moments. Thus the perspicuous Mackenzie King, official capital planner par excellence and enterprising aficionado of the picturesque ruin, sought to resolve his 
The Signature of the City: Abandonment and Dreaming in Colonial Williamsburg and Ottawa

commemorative legacy both in living official architecture and in the ruin. His passing observations about nature and the wilderness glimpse a very distant horizon where the two are joined.

Thinking the capital-as-ruin also suggests human as well as natural ways that 'official' memorybearing architecture may be absorbed back into a landscape. It sets up the terms for an architectural struggle between what evolves more or less organically in the urban fabric versus the state's conscious plan designed in part to perpetuate the national legacy. Of Ottawa's wild and semi-industrialized riverbanks Mackenzie King dreamed of garden promenades and parkways, of the rag-tag architecture then surrounding the Parliamentary precinct he dreamed of state-ownership and Haussmann-like boulevards with open prospects towards the Parliament (GORDON, 2002). He told the Parliament that his dreamt capital was home not only to "government and diplomacy” but also to "art and architecture" expressed in heritage, cultural and research institutions. Developments that "those who may follow in future years will come to recognize as an expression in some degree of the soul of the Canada of today.” (HOUSE OF COMMONS, 1928, p. 2321).

\section{Abandonment}

What a capital loses when it ceases to be the seat of sovereign power are those essential qualities that differentiated it from other urban forms. Underpinning any typology of capital cities will be their status as the primary spatial referent of sovereignty. Thus King described Ottawa to the Parliament as "the focal point...to which all eyes of the Dominion are turned.” (Ibid., 2320) As Daum and Mauch write, "all capitals share the fact that they are privileged vis-à-vis other cities within the same political system.” They describe a capital as a "multiple hinge [that] mediates between its urban space, the surrounding society, and the nation, no less than between the nation-state and the international world.” (DAUM; MAUCH, 2005, p.3). Linguistically, officially multilingual capitals like Ottawa act as a hinge between recognized language groups. They stand in also as synecdoche for their nations in news reports that say "Washington demands" such and such or "Ottawa announced" this or that.

As Piano observes above, a city is self-organizing as well as planned and it carries out its own message in a manner akin to a linguistic 'performative.' In a capital city, this is expressed in the pattern of government organization, architecture, urban planning, state pageantry, commemorations, religion, historiography, and even in protests and other expressions of popular culture. National capitals are 


\section{Mark Kristmanson}

special zones of national representation and, as argued above, they are monumental and legacy forming. On the other hand, the signature of a capital also is associated with its unconscious 'style' of civility, as expressed in various latent cultural forms that may or may not be reflected in the city's plan, national institutions and architecture. When abandonment occurs, and these distinctive qualities of a capital evaporate or are transferred to the new power centre, one expects latencies to emerge.

Williamsburg's abandonment as Virginia's colonial capital had its precise hour. On June $8^{\text {th }}$, 1775, the last Royal Governor, the unpopular Lord Dunmore, vacated his official residence to join his family on board the HMS Fowey lying nearby in the York River. That morning of strange emptiness in the Governor's Palace effectively marked the end of Williamsburg's service as a capital of British imperial power. From 1699 onward it had been at once a nerve centre of British rule in America as well as the intellectual cradle of revolutionary resistance, fostering the emergence of key founding figures such as Thomas Jefferson, Patrick Henry, and George Washington. By the end of the war, following Lord Cornwallis's surrender to Washington at nearby Yorktown in 1781, the victors had already moved the Virginian capital to its current location in Richmond and Williamsburg had begun its period of decay ${ }^{8}$.

Its near miraculous resurrection as a town-sized historical museum in 1926 followed almost a century and half of obscurity and neglect. To visitors during the intervening period it seemed that the structures that marked it as a former capital had all but disappeared and that the town would be venerated only in the nation's written history. Restored to the halo of official Washington's grandeur by the fervor of a local cleric and the intense philanthropic interest of John D. Rockefeller Jr., it became both the living tomb of British gubernatorial power and the dead centre of the founding of American democracy.

There are thus two paradigmatic transpositions to consider: Williamsburg's transition from a fully functioning eighteenth-century colonial capital to a dormant town approaching 'ruin' in the nineteenth century, and from the 'ruin' to its current status as a 'capital' living history museum. Viewed from an architectural perspective, these transitions occurred both in terms of form and function, as the use and meaning of Williamsburg - its signature - was radically and doubly reinscribed. $^{9}$ 
The Signature of the City: Abandonment and Dreaming in Colonial Williamsburg and Ottawa

\section{Nature}

During the occasional trip on a commuter train in city like London or Paris one's eye is drawn to the festive invasion of ivies, hollies, brambles and thorny overgrowth forming impenetrable tangles along untended sides of the rail lines. In Williamsburg, not only is there English Holly, but also Witch Hazel, Virginia Creeper and a plethora of vines, mosses and grasses all poised to reassert their supremacy when the discipline of the garden gives way to the intensity of the wilderness. Similarly, a proliferation of utilitarian architecture can easily bury iconic places in a capital. For instance, until their discovery in 1989, the foundations of Shakespeare's now rebuilt Globe Theatre were lost to memory beneath a South Bank parking structure.

Without doubting the sincerity or ability of those undertaking the restoration of Colonial Williamsburg starting in 1926, Paul Wilstach’s classic Tidewater Virginia (1929) hinted at the magnitude of reversing more than a century of both man-made and organic overgrowth. "Jamestown survives in some few ruins," he wrote, and of Williamsburg itself, "only the foundations of the Capitol remain.” (WILTACH, 1929, p.171). From the living, vibrant capital where Virginia's and even America's future would be decided, Williamsburg had become, if not obliterated, primarily reserved as a place for nostalgia:

Sometimes only a leaning dormer or the distinctive outline of a Georgian chimney cap identified instances of colonial buildings swallowed up by later renovations and repairs. The general feeling conveyed to the perceptive visitor was one of bittersweet sadness for the ordered beauty that had once been. (YETTER, 1996, p.10).

Although 'abandonment' should not be read simply for nostalgic evocations of a capital's ruined remnants, such nostalgia does crop up frequently in the accounts of nineteenth-century visitors to Williamsburg. Underscoring the nostalgic impulse is uneasiness about how utterly forgotten and overgrown a city may become, once it is abandoned. It is as if monumental architectural expression struggles to surmount what already in the nineteenth century was a truism: that all will be forgotten eventually in the ineluctable passage of time and the reassertion of the state of nature ${ }^{10}$.

Reading George Yetter's collected visitor accounts of postcolonial Williamsburg one finds a continuous presentation of an underlying state of nature, as if abandonment relaxed a ban or limit placed on the natural world by the sovereign power in its capital. After the decisive defeat of the British under Cornwallis at Yorktown in 1781, the French General de Rochambeau wintered in Williamsburg 


\section{Mark Kristmanson}

and it was during his occupation that the Governor's Palace burned to the ground leaving the city bereft of its second most important building. The elimination of key architectural symbols such as the Capitol and the Palace signaled a reassertion of nature as early as 1783 when a nostalgic visitor wrote:

There's the Capitol, in which the fate of Empires has been decided like that of ancient Rome...alas how changed! The seat of Empire removed, Commerce at an end by the fury of a civil War. (YETTER, 1996, p.32).

In 1793, the forlorn town was described as "dull, forsaken and melancholy" and in 1816 a visitor deemed that there was "very little to recommend it [...] xcept the memory of its ancient importance [...] ifeless [...] but the shadow of itself, and even that seems passing away." Notwithstanding General Lafayette’s return in 1824 for a "brief moment of glory [...] Williamsburg truly was a town that time forgot," and in its dormancy "there definitely were suggestions of the sleep of Rip Van Winkle.” (Ibid., p. 33-35).

In 1835, Lord Dunmore's grandson visited and judged the town beyond even the nostalgia of ruins:

\footnotetext{
The centre of the palace [...] has long since fallen down, and even the traces of its ruin are no more to be seen [...] with what mingled and indefinable feelings I viewed this spot [...] where my grandfather had lived, surrounded by the pomp and pageantry of vice-royalty! - then all was bustle, and gaiety, and life within those halls[...]. What is now the contrasted scene? [T] he ancient capital, on the site of which I was now standing, has dwindled, in half a century, into a paltry village, without even a venerable ruin to rescue its decay from insignificance! ( Ibid., p.36-37).
}

Creepers and animals are the indices of its decline. In 1827, an incoming professor at the College of William and Mary wrote: "I thought I was transported to Noah’s Ark, when I first came to this town, so prodigious was the quantity of animals I met with, without seeing a single person.”11 (Ibid., p.4) Another visitor noted in 1876: "In the Palace grounds, or rather what were formerly the Palace grounds, is a large earthen mound. Trees have grown on it, and the bamboo briar and Virginia creeper run riot there.” In 1900, a reporter allowed that "before the rank growth of summer weeds [there was] some dignity, even in the decay.” (Ibid., loc. cit).

The ubiquitous presence of domestic animals in the early illustrations and photographs of Williamsburg was carried over into the official guidebooks: for example, when "Mrs. Spencer's rooster chased Mrs. Filbate's hen across the street, they raised such a cloud of dust," or "Peyton Randolph 
The Signature of the City: Abandonment and Dreaming in Colonial Williamsburg and Ottawa

Nelson grazed his cattle on Williamsburg's greens during the 1920s. His herd of western ponies often thundered down to Duke of Gloucester Street to forage in the town.” (Ibid)

The unglamorous town continued on with a depleted core of respectable families nourishing its evocative memory as a capital city. Visitors noticed rootless opportunists superseding the worthy yeomen of colonial times. This decline in historic purpose chimed with random modernization altering the neo-classical aesthetic prescribed by Governor Francis Nicholson’s original capital plan:

[M]any old houses had been embellished with Victorian porches; others were quietly rotting away with tottering walls and sway-backed roofs. Chickens scuttled out of the ruts in Duke of Gloucester Street as oxcarts creaked past ${ }^{12}$.

The nadir of Williamsburg's transition from colonial capital to 'ruin' occurred with the coming of the automobile and "grease-stained filling stations slapped together with sheets of corrugated iron. Utility poles paraded down the middle of Duke of Gloucester Street, sprouting skeins of overhead wires.” Fusing vulgar modernization with high archeology, one account records that "a tin garage near the Magazine bore the sign 'TOOT-AN-CUM-IN.'”13.

It was in this reduced condition that the first champion of Williamsburg's restoration, Rev. W.A.R. Goodwin, launched the idea of a restoration project. In the spirit of Frank S. Dehass's Buried Cities Recovered (1882) - the first book Goodwin had acquired as a boy - he sought to restore symbolic evocativeness to the former capital city starting with the church. Indeed, as nature had progressively reasserted itself over the old town, the buried capital-as-museum was emitting alarm signals: “every twisted shade tree, from every mossy, sagging fence, the past cried out to those who would listen.” (Ibid)

In principle, as the case of Williamsburg shows, any place can become a capital, and any capital can revert to a state of nature. Thus, the state of nature, as Giorgio Agamben (1998, p.105) writes, "is not a real epoch chronologically prior to the foundation of the City, but a principle internal to the City, which appears atthe moment the City is considered tanquam dissoluta, as if it were dissolved.”. Although Agamben does not mention abandoned capitals as such, he treats cases where the relaxation or interruption of sovereign power reveals an underlying political relation. In the capital city's role of legitimating state authority there is a need to suppress or harness the state of nature as part of the apparatus of governance. With abandonment comes a release from this responsibility, a relaxation that had to be reversed in the recuperation of Williamsburg as a living history museum. 
Forming more than half of the Williamsburg's colonial-era population, enslaved African Americans starkly present the 'bare life' that for Agamben is the ground of sovereign authority. He argues that a society's governing authority is defined at the outset by a decisional power over the human who can be killed without legal sanction (homo sacer), and this absolutely primary sense of 'abandonment' to bare life - a 'ban' on those, such as slaves, designated to be outside the law - is what founds any given society. On this view, the original political relation in Williamsburg would be slavery, not incipient American democracy ${ }^{14}$.

Taken to the extreme in this capital-as-museum, Williamsburg lays bare what in Ottawa, for example, might only be hypothesized: that the internal signature of the polis lies precisely in the relation of sovereign power to bare life. It is in this relation that civic order is manifested as a community, and it determines what form civility will take. 'Civil' is the key term here, one whose original Roman meaning signified the garland of acorns and oak leaves granted to one who had saved another's life $^{15}$. I suggest that this notion of sparing a life marks the potential for people to form communities in empirically bound space and time, just as the taking of a life without sanction defines the potential tyranny in the leader.

The interpretive critical terrain that this opens up in the case of Colonial Williamsburg as a living history museum, a place imaged so forcefully as the birthplace of American democracy, lies beyond the scope of this essay. There is a "distanciation effect” in Agamben's thought that would, in such a discussion, make it more difficult to interpret Williamsburg within a narrative of gradual evolution towards liberty and equality in American democracy ${ }^{16}$.

For present purposes, the notion of the city harboring a latent "state of nature" that fluctuates in relation to the presence of sovereign power can, as suggested by the examples above, be applied to urban space. It follows that there is an architectural dimension of 'bare life' in the colonial period takes spatial form as pasture for animals, outbuildings, slave quarters, 'Indian Territory', and as waste areas that by their exclusion define official boundaries. Architectural 'bare life' is the uncoordinated capillary development of buildings and urban landscapes that softens or erases their historical symbolism. These latent aspects emerged to alter the signature of the abandoned capital of Williamsburg as it veered towards the ruin. As such, the observations of visitors to post-colonial Williamsburg can be read not purely as nostalgia but also as indicators of this unmarked feral quality that persisted during its capital era and then, in abandonment, crept back into view. 
The Signature of the City: Abandonment and Dreaming in Colonial Williamsburg and Ottawa

Natural references punctuate Mackenzie King's diary entries during his visits to Williamsburg starting in 1937. His first dream while staying at Williamsburg featured his beloved terrier Pat accompanying him into a session of the Canadian Parliament: "I walked through the lobby...Pat following very closely, not minding the members and [with] an attitude of having a complete right to do so.” (WMLK DIARY, 27 April 1940). Here, the Prime Minister dreamt the forbidden equality with animals as unremarkable traffic in the Canadian legislature.

Returning to Williamsburg in March 1945 for a short visit "amid all the quiet of the old town with its white painted buildings and fences," King commented in passing on the natural surroundings:

Went for a walk up to Mr. Rockefeller's residence and through his grounds [...] It was a delight to see [...] forsythea coming into bloom. Later periwinkle and daffodils. Above all, bits of green grass. Also saw a Cardinal bird [...] It was wonderful to hear the birds singing for all they were worth in the little forest. Trees covered with ivy and other trailing plants. (WMLK DIARY, 28 April 1940).

During his next visit, extended by illness, King "walked to see where the deer come to lick the salt. It has been a lovely sight to see these little creatures come out of the wood towards evening. It reminded me much of Kingsmere.” (Ibid, 15 April 1947). A bout of influenza made the hypochondriac King, at all times obsessively aware of temperature and humidity, especially sensitive to the climate. “Leaves coming out rapidly,” he wrote, "shrubs beginning to blossom. Dogwood showing itself. All spring beauty bursting forth. Grass very green. Sunlight on the grass gloriously bright.”

Often the appearance of flora and fauna in King's stream of consciousness corresponds with noticing the presence of African-Americans in Williamsburg, as in this case where he goes on to describe being carried around the town by "the Williamsburg white horses and conveyances and coloured driver.” He visits Chorley and his wife in their kitchen "converted from slave quarters” and listens to six African Americans sing spirituals:

The combined voices were like the tunes of a beautiful organ. Very soft and sweet. One felt the emotional nature of the darkeys and what religion, as they call it, means to them. Sang songs of Old Virginia and others. (Ibid, 20 April 1947). 


\section{Mark Kristmanson}

Conversation with Chorley then shifted to talk “about some of Mr. Rockefeller's large interests [...] his characteristics and the development of Williamsburg.” The place of African Americans in Colonial Williamsburg hovered on the edge of his thoughts, touching down again after watching a film at the Lodge portraying the early days: "picturesque sort of scenes with wigs, plush, etc. and an age for the fashionable and well-to-do people but a society based on slavery.” In an uncharacteristic commentary, he added, "no wonder the masses are beginning to fight for all they are worth to come into equal opportunities to and equal shares in the world's wealth.” (Ibid., 16 de April 1947).

It is arguable that King's diaries of this period, at times approaching free association, reveal a reflex towards nature that abhors the very public and high official status he so patiently had constructed for himself. During Chorley's Ottawa visit, for example, as he considered the invitation to the Williamsburg convocation, he breaks off:

\footnotetext{
As I have been dictating, I am looking out of the window at the sundial. A bluebird has come and settled on the peak of it. Flies down on the ground and files back up again a perfectly lovely sight [...] no birds have been around at all...This little symbol of happiness at the moment is very beautiful to think of, particularly with little Pat lying at my feet sound asleep. (Ibid., 31 July 1947)
}

He wanted Kenneth Chorley to share in his feeling so he took him up the road to his farmhouse, Moorside, "where fortunately the distant blue was quite at its best." Perhaps the guest from Virginia sensed something of the awe-inspiring chthonic force of northern wilderness before he returned to the South. According to King, he "thought the whole beauty of the place very great." On the other hand, that Chorley "liked its wild naturalness" hardly captures the full force of the fact that Canada's capital city is balanced precipitously on the cusp of a great and unbroken wilderness that extends northwards all the way to the Arctic.

\section{The Capital-as-Museum}

The resurrection of Virginia's colonial era capital from 1926 onwards as the world's largest living history museum is a remarkable recuperation of the symbolic value of a capital city vested in its heritage layer. All the while that a capital city performs its manifold ongoing functions as the seat of sovereign power, parallel processes of historicization and museumification are working within it to reinforce the legitimacy of the state, its founding figures, its sustaining narratives, its honorifics, 
pageantry and commemorative foci. Taken in conjunction with written history and archaeology, the museumification of a capital starts with its monumental plan and dominant architectural vocabulary. These aesthetic statements gain meaning as they sediment in time and foster institutions dedicated to the preservation of public memory that in turn accumulate statuary, relics, trophies of war, artworks, literature, and other material culture evoking the everyday life of previous epochs.

Abandonment thus precipitates what might be described as a historical "legitimation crisis" for a capital city accustomed to the status and prerogatives of power. It is a test that Williamsburg, notwithstanding its historical centrality in the founding of the United States of America, would not have passed but for the extraordinary philanthropic interest of John D. Rockefeller Jr. The latter identified so strongly with its symbolism that he progressively took over Rev. Goodwin's dreamt restoration with seemingly endless funding to realize it.

When Rockefeller came on the scene in 1926 the town's museal layer was reduced to a depleted stock of much-modified domestic architecture whose colonial-era material culture was dispersed. Its primary symbols, the Capitol and Governor's Palace had long since disappeared. Resurrecting its colonial-era built heritage meant restoration on a grand scale. As the work proceeded, the 'state of nature' was pushed back and the town's museal layer was brought to the surface. The overgrown foundations of the Capitol and the Palace were cleared and, with varying approaches to exactitude, simulacra were created for these and dozens of other structures.

In Williamsburg's capital-as-museum model the restored town took shape as a sanitized version of its colonial era forebear. In its neat and almost suburban American aesthetic the natural world became tightly controlled even at the expense of historical authenticity. A guidebook from Colonial Williamsburg treats this question rhetorically in an opening paragraph asking if various eighteenthcentury residents would now recognize the restored town, including "the slave who lived in Williamsburg as a spy for General Lafayette in the days leading up to Yorktown?” Would he “rediscover the outbuildings and dark attics that blacks frequented?” The response provided, a “qualified yes,” had certain pertinent caveats:

But the paved streets, the brick sidewalks, the streetlights and the fire hydrants would be strange to eighteenth-century eyes [...]. The whole town would seem tidier [...] better painted [...] more smoothly cropped [...]. They would miss the dozens of saddle and draft horses [...] the cows, chickens, sheep and other livestock in every part of town; the streets and paths mired with mud or deep in dust; and the clouds of flies and mosquitoes in summer. Perhaps most of all they would miss the pungent smells of animal manure, rooting hogs, backyard privies, and unwashed humanity. Obviously 


\section{Mark Kristmanson}

[...] it would be impossible to revert fully to the customs of the colonial period or to tolerate the lack of sanitation that prevailed. anymore ${ }^{17}$.

There is no reason to question the operational impossibility of recreating the sensorial experience of the colonial era. Nor is this the occasion to plumb the vicissitudes of historical 'authenticity'. It is worth noting, though, the aseptic hand of J.D. Rockefeller Jr., whose personal attention to detail, combined with considerable executive ability effectively erased any trace of the town's period of abandonment. His was a narrowly defined "authenticity" that operated in selective ways to favor a cleaner, exclusionary and, in effect, a more modern, signature for Virginia's colonial capital. ${ }^{18}$ As Anders Greenspan writes, "For JDR Jr., if something was to be done, it had to be done properly or not at all.” This was his signature: an "insistence on accuracy, authenticity and precision.” Above all, "he was "a perfectionist of the highest order and took the greatest care in most things, even

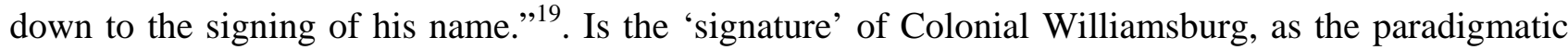
case of a capital city in its full-blown museal state, finally more "Rockefeller" than the glorious nation builders it loyally commemorates? In this quest for personal legacies lies a direct connection between Rockefeller's Williamsburg with Mackenzie King's Ottawa. The association of the two men had preceded their respective dreams of capitals past and future. As a young labour relations expert King had been employed to mitigate damage to the Rockefellers following the ignominious 1914 Ludlow Massacre when their agents lethally machine-gunned striking miners and their families during the bitter Colorado coal strike. A friendship was maintained and, as the two men grew older, they cooperated and competed in respective attempts to leave public legacies.

Beyond Mackenzie King’s consequential ambitions for shaping Ottawa as a capital city, it was his relationship to JDR Jr. that brought him into the orbit of Colonial Williamsburg. From his first visit in 1937 (the year that JDR Jr. went public with his ideas about the restoration's objectives) to the time of his death in 1950 (just after Rockefeller had handed control of Colonial Williamsburg to his son), King was both a regular witness to and a roving ambassador for Rockefeller's massive heritage initiative. For one thing, it stirred his fetish for ruins, a fixation that was an ongoing burden for his aides and officials who helped procure stones and gargoyles for a series of architectural follies he erected on his country property at Kingsmere, Quebec ${ }^{20}$. Moreover, he was fascinated by Williamsburg's complete 'museumization' as a capital and what this could mean for Ottawa.

Perhaps it says something about Canada's character that the selection of its capital city in 1857 preceded by ten years the actual foundation of the Canadian nation ${ }^{21}$. Far from a 'dream capital' 
The Signature of the City: Abandonment and Dreaming in Colonial Williamsburg and Ottawa

evoking Europe's metropolitan boulevards, the raw wilderness setting of the future capital demanded long vision and great optimism. Only in these far sights could a capital be dreamt of that would appropriately accommodate and valorize the nation's Parliament, its political leadership, national institutions and the embassies of foreign nations. The well-traveled King had suffered immediate dejection upon his first arrival in Canada's far-flung capital-in-the-making in 1900 and he had made it a lifelong project to realize in Ottawa the dream of a distinguished national capital.

At the outset of his first visit to Williamsburg he had responded warmly, noting in his diary that:

It was one of the most interesting days I have spent anywhere; the work of restoration of the town as it was at the time of the original settlement has been exceptionally well done. Buildings restored and refitted with attendants dressed in the period of the time; the whole giving one a very complete picture of the earliest English settlement in America, and what may be termed the 'cradle of the American Nation.' (WLMK DIARY, 18 March 1937).

Beyond the "fine dignity and beautiful feeling of true proportion about the lay-out of the town, and the style of buildings," he noted that, "The Duke of Gloucester street with the Capitol, at one end, and the University, at the other, represents an ideal relationship in education and Government.” Inside the Capitol, he was delighted that "the old prayer book of the reign of George I contained prayers identical with those now being used in our House of Commons”.

King found a certain 'Britishness' still palpable in Williamsburg and "could not help thinking...that since the time the town was occupied in the manner in which it is reproduced today, Canada had passed from French possession into British, and the United States, from a British country into an independent nation." He was struck that he "should be speaking with the President [Harry S. Truman] very much as we both might have spoken as citizens of one country 330 years ago.” He noted the "remarkable parallel between Williamsburg, as the place of earliest settlement and Government in the United States and Quebec in Canada”.

King pursued this theme with President Truman and with Canada’s Governor General, Lord Alexander, suggesting to them that the King George VI and Queen Elizabeth should visit Williamsburg as an extension of their upcoming visit to Washington. Thought finally it was not included in their itinerary, King mentioned the missed opportunity to the royal couple when months later they dined at Laurier House, his residence in downtown Ottawa. To his delight, the Queen replied, "I was most anxious to visit Williamsburg. It is the one place in the U.S. I would liked to have seen.” Encouraged, 


\section{Mark Kristmanson}

King sought Her Majesty’s opinion on deeding Laurier House, and perhaps Kingsmere, to the Canadian government in a manner along the lines of Colonial Williamsburg. Laurier House could be "kept as a sort of Museum in connection with its historic interest” as the former private residence of two Prime Ministers. The Queen advised him immediately to get down to completing his will ${ }^{22}$.

King visited Williamsburg again in 1939, 1940, 1945 and 1947 for stays of varying lengths, hosted either by JDR Jr., members of the Rockefeller family or by senior staff at Colonial Williamsburg. His visits to the plantation house at Carter's Grove and particularly the house in Yorktown where Cornwallis surrendered to Washington refined his idea of leaving his Ottawa properties as a public legacy. With that unabashed comparison in mind he wrote that these sites "offered an excellent suggestion as to what could be done with Laurier House. Some small admission. Rooms roped off so that they could be looked at from the door. Much the same as Washington's home.”

Kenneth Chorley inspected Laurier House during his Ottawa visit and deemed its substructure better suited to public visitation than Roosevelt's house at Hyde Park. King saw no flattery in Chorley’s firm message about guarding his legacy: "He kept saying one must look ahead - fifty, 100 years. The whole meaning of everything would be much greater to younger generations.” King added, "I am sure this is right." At Kingsmere, Chorley was "immensely taken with the whole view...particularly with the ruins."23 (Ibid, 30 July1947)

During the evening at Kingsmere King expressed his reservations about the pressure of extra travel involved and the strain of preparing an address, but adding luster to his legacy was irresistible:

It came to me in the early morning that this really was something I should accept. My name has a certain association already with Williamsburg and Mr. Rockefeller. The whole historic setting one's place in British history, etc. would make it a significant honour indeed. Also it would be pleasant to share a couple of days with Lord Alexander there. To receive a degree at the same time as he did from the University. Harvard is the oldest, and William and Mary, the next. It could be part of the history of this continent and of the British Empire which could be a worthy recognition in connection with one's life work and associations. (Ibid.).

The matter decided, King turned to discussing the development of Ottawa as a capital city: "I was able to show him how the whole city was being planned." After touring the Parliament, King reported that Chorley "was perfectly delighted with the painting of myself" seen among those of previous Prime Ministers: 
He [...] spoke of different ways it resembled Mr. Rockefeller's portrait. I showed him what the papers were in my hand with Attlee's signature showing. It was this that caused Salisbury to think of showing Rockefeller's name in the portrait of himself, attached to papers relating to his gift of millions to purchase land, etc. for the U.N. building ${ }^{24}$.

It was King who had suggested British portraitist Frank Salisbury to JDR Jr. and their parallel portraits, each grasping important documents, signals the amicable contest between plutocratic munificence and Prime Ministerial power, between restoring a capital as it had been and building a capital worthy of the future ${ }^{25}$. Though not totalitarian, there is a suffocating quality to Mackenzie King's self-honoring 'museumification' of Canada's capital, nurtured by his competitiveness with Rockefeller. Additional official portraits now grace the corridors of Parliament and the public's memory of King has softened rather than intensified. The built legacy of the King era persists, including the historic sites at Laurier House and the much-loved Mackenzie King Estate at Kingsmere $^{26}$. But his imagined capital city, now reworked by other planners and bearing later contributions of Pierre Elliot Trudeau and other leaders, has been overgrown and built upon in ways that he could not have imagined.

\section{The Signature of the city}

Utopic traces are secreted within the layers of a capital city. This essence, pressed beneath the weight and force of official architecture, is the faintest hint of a place where man and nature remain indistinct. It does not escape photographer Mimo Jodice as he passes with his camera through fish markets, bakeries and kitchens, that the image of the still life "presages the loss of a way of knowing empirically in the world.” This serves as a reminder, he says, "that Eden is all around us watching from the dark corners" ${ }^{27}$. He brushes up against the edge of a paradox that suggests that the signature of the city, as found in its unofficial spaces, can be glimpsed only in the moment of its forgetting, and as such is elusive to history.

Is it conceivable that the signature of the city might be discernable outside of written history in spatial and even acoustic terms, as Renzo Piano suggests? In this vein, the signature is incommensurate to the efforts of planners. Listen to it, Piano says, and the city will reflect its multiple histories. ${ }^{28}$ Edward Herbert wrote in 1633 that "the goodness of a thing lies in its internal signature,” and Agamben 
elaborates this with Lermolieff's argument (presaging Freud) that the true character of things is found where there is less emphasis ${ }^{29}$. For his part, Bollas doubts that a city can be consciously 'planned', remarking that, "the totalitarian conception of the city is always in the realm of the conscious," and that it is an error to believe that "consciousness alone can form a city.” (BOLLAS, op. cit, p.56).

Against this is the belief that the signature of a capital city results from the personal influence of great and powerful people on that city's plan and the monumental architecture erected at their command. Thus Hitler's remark to his architect and planner Speer, "our opponents will come to realize it, but above all our followers must know it: our buildings are built with the aim of strengthening... authority.” (WISE, 1998, p.129). In the case of Ottawa, Mackenzie King was the politician most determined to leave his mark upon the Canadian capital and arguably the most successful in doing so. Colonial Williamsburg is the result of JDR Jr.'s similar determination.

These individual legacies may seem quite sufficient to constitute the main significance of richly evocative cities. Indeed, it would be unwise to discount the causal significance either of 'great men' or macro economic forces. Yet, the internal signature of the city surely is more elusive, dwelling partly in the realm of the unconscious, the unintended and in the unconscious rapport with the natural world. As such, the horizons of the dream and of abandonment help to circumscribe this indefinable essence.

As the College of William and Mary’s Spring 1948 convocation approached Mackenzie King agonized over his address. Pressures of office continually caused him to break off from the task until the last possible minute, on the Easter weekend, when he summoned staff members to Kingsmere to help complete the speech. In these diary entries a disjuncture emerges between the constricted speech, with its ponderous theme of freedom versus communism, and a palpable sense of release in King's parallel evocations of nature.

King sought to address meaningfully "the saving of the soul in the mind which is what Communism seeks to destroy." Hardly clarifying matters, he wrote of "the greater importance to a nation as to an individual of its soul compared with which the body is nothing; so beware of him that has power to destroy the soul.” After working on it “solidly all morning,” King looked outside:

A beautiful bright day. Snow has pretty well gone in the city but as we got into the hills at Kingsmere, it became plentiful...the scene was one of quite exceptional beauty. 
The Signature of the City: Abandonment and Dreaming in Colonial Williamsburg and Ottawa

The trees had become covered with ice but not sufficient to bear them down [...]. What was most beautiful of all was $[\ldots]$ the very tops of the trees $[\ldots]$ the ice was melting, the drop of water took on more and various colours of the spectrum [...] the richest possible colours...not only the beauty of the trees in this marvellous army of colour $[\ldots]$ but hearing the robins singing [...] it is a delight to see the squirrels round about and catching glimpses of other birds. Mrs. Kelly [...] saw 3 deer licking the salt [...] I missed little Pat very much [...] a little talk [...] about arrangements for the horses. The bees $[\ldots]$ are doing well. Already swarming about [...] further revision of my speech which kept us until nearly 11 [...]. It seemed impossible to get just what one wanted to say, into shape in the final paragraphs. I left the matter over until tomorrow. (WLMK DIARY, 27 March 1948).

Arriving in Williamsburg, King's nervousness increased when Chorley informed him of “tremendous precautions the secret service [were taking] in regard to Truman's visit. Every servant in the place checked over.” Colonial Williamsburg’s administration, King learned, "had to take a hand in pretty much all the arrangements... Mr. Rockefeller had always insisted on anything being done, being done in the right way and without any fault.” Sitting in front of the Chorley's fireplace in "what was once slave quarters," King showed him the speech: "I had thought I should say something on freedom... I could hardly come to a great University and not make some reference to a world situation.”

Suffering fits of chill and fever, King bundled up and took a long walk "around the green which stretches into different vistas. For a few moments, he forgot about speaking on the very ground where Patrick Henry so famously had exhorted fellow patriots to resist British rule, and in this interstice something joyful revealed itself. “Trees coming down to the grounds on all sides," he wrote, "it was thrilling to see the tiny forget-me-nots, other little flowers nestled in through the grass, the buds of different varieties coming out on the shrubs, the forsythea and other shrubs in bloom.”

No such evocation of nature would lighten his address the next day. President Truman had been fogbound in his yacht and by the time the ceremony finally started King was in a state of petrified nervousness:

We all assembled in a large hall, subsequently marched to the front of the building... Students and guests massed back to the roads and old buildings on different sides. I wished very much I had not brought the red Oxford gown. It was far too conspicuous. The cap too was a sloppy looking thing. Why I do these things, I don't know... I was fearful through it all, and in speaking found it difficult to avoid coughing. Did some coughing and, on the whole, I felt the speech went well. ${ }^{30}$ 


\section{Mark Kristmanson}

The signature of the city, in the case of Williamsburg, could not be that of John D. Rockefeller Jr. alone any more than it could be attributed to any leadership figure of the colonial era. He succeeded in suspending the signature in historical animation. It remains deferred to some future moment of reckoning or reconciliation. As for Mackenzie King, his prim but dignified hand authorized the ambitious Gréber Plan for Canada’s capital. His city and country residences, one in Ontario and one in Quebec, indeed were converted to museums dedicated to his memory. As a result, his mark remains evident on a capital city that bridges two official language cultures, whose primary reference is extreme cold, and where a true wilderness lies just at the doorstep.

Yet, the processes revealed in the dreaming of capitals and in their abandonment - including the latent forces of nature and museumification - could never converge in the commemoration of a single historical figure. Rather, they help trace the city's long, slow and unobtrusive signature that is constantly re-inscribed at the edge of our consciousness.

\section{Notas}

${ }^{1}$ William Lyon Mackenzie King (WLMK) diary, 31 July 1947.

2 David Gordon, “William Lyon Mackenzie King, planning advocate,” Planning Perspectives 17 (2002) 97.

${ }^{3}$ Currently, sixty-five existing or former capitals are accredited as UNESCO World Heritage Sites. For example, of Damascus, one of the world's oldest continuously inhabited capitals, Stefano Bianca, Conservation of the Old City of Damascus, Paris: UNESCO, 1987, p. 3, writes: "the present physical pattern of the city intra muros is the outcome of an 'overlay' of Islamic period structures on a Roman-Hellenistic grid system...many archaeological traces of the pre-Islamic period have survived, partly hidden under later structures.”

${ }^{4}$ Paul Wilstach, Tidewater Virginia, New York: Blue Ribbon Books,1929, 120.

${ }^{5}$ Laurent Vidal, “D’aeroplis à acropolis, les paraboles de Brasilia,” in Brasilia : L'épanouissement d'une capitale, Paris: Éditions J. and A. Picard, 2006, 170-171, notices how the 1987 UNESCO heritage designation of Brasilia’s “Plan Pilote,” in “a strange irony of history,” now protects this world icon of modernism from 'modernization.'

${ }^{6}$ Jacques, Gréber, "Plan for the National Capital of Canada,” Journal of the Royal Architectural Institute of Canada 26:12 (1949) 401. (Emphasis in original.)

${ }^{7}$ House of Commons, Canada, Debates, 24 April 1928, 2321.

${ }^{8}$ See George Humphrey Yetter, Williamsburg Before and After: The Rebirth of Virginia's Colonial Capital, Williamburg, Va.: The Colonial Williamsburg Foundation, 1996.

${ }^{9}$ Thomas Whyte, “How buildings mean: some issues of interpretation in the history of architecture,” History and Theory 45 (May 2006), 174, usefully introduces Mikhail Bakhtin’s notion of genres and translation into architectural historiography, arguing that it is possible "to trace how each of these different transpositions make up the work as a whole... how 
architecture changes through time, as alterations in use, in taste, and in environment transform responses to a building, an architect, or a critic.”

${ }^{10}$ It was said of Maxime Du Camp that his documentation of Paris was born in a moment of archaeological epiphany: "It suddenly occurred to this man who had traveled widely in the Orient, who was acquainted with desert sands made of the dust of the dead - that this city, too, the city bustling all around him, would have to die someday, the way so many capitals had died.” Paul Bourget, “Discours académique du 13 juin 1895 : Succession à Maxime Du Camp,” in L'anthologie de l'Académie française (Paris 1921), Vol. 2 pp 191ff. (Cited by Walter Benjamin, in Selected Writings, Vol. 4.)

${ }^{11}$ Ibid., 4.

12 Colonial Williamsburg Website: "History of the Restoration," http://www.history.org/foundation/general/introhis.cfm (visited 12 November 2010).

${ }^{13}$ Colonial Williamsburg Website: "History of the Restoration,” visited 12 November 2010 at http://www.history.org/foundation/general/introhis.cfm

${ }^{14}$ Agamben, op. cit., 28-29: "He who has been banned is not, in fact, simply set outside the law and made indifferent to it but rather abandoned by it, that is, exposed and threatened on the threshold in which life and law, outside and inside, become indistinguishable... The originary relation of law to life is not application but abandonment.”

15 OED

${ }^{16}$ Colonial Williamsburg's Internet web-page, 'Framework for Explaining Change,' states: “It is a story that tells how diverse peoples, holding different and sometimes conflicting personal ambitions, evolved into a society that valued both liberty and equality. Americans cherish these values as their birthright, even when their promise remains unfulfilled. At stake always have been the aspirations of ordinary people. The philosophical and constitutional principles that validated those aspirations came later.” http://research.history.org/Historical Research/Framework.cfm (visited 12 November 2010).

${ }^{17}$ Colonial Williamsburg Official Guidebook and Map, $7^{\text {th }}$ edition, Colonial Williamsburg, 1972, v. In 2010, despite earnest attempts to appropriately represent slavery, there remain uneasy evocations such as the children's toy "slave set," complete with chains and a wooden spoon, sold in the Visitor Centre's gift shop.

${ }^{18}$ Yetter, op. cit., 54, cites JDR Jr.: "The restoration...offered an opportunity to restore a complete area entirely free from alien or inharmonious surroundings.”

${ }^{19}$ Creating Colonial Williamsburg, 9

${ }^{20}$ See Dennis Duffy, “Love among the ruins: The King of Kingsmere,” American Review of Canadian Studies 37:3 (Autumn 2007), 355-70.

${ }^{21}$ See David Knight, Choosing Canada's Capital: Conflict Resolution in a Parliamentary System, Ottawa: Carleton University Press, 1991; David Gordon, “From noblesse oblige to nationalism: Elite involvement in planning Canada’s capital,” Journal of Urban History 28:1 (November 2001) 3-34.

${ }^{22}$ WLMK diary, 20 May 1939. King acquired the private home of Sir Wilfred Laurier, his predecessor and mentor, in 1923. The Canadian Government did not provide an official residence for the Prime Minister until 24 Sussex Drive until 1951.

${ }^{23}$ Ibid., 30 July 1947. 
${ }^{24}$ Ibid., 31 July 1947. King was depicted holding documents sent by British Prime Minister Clement Attlee concerning the 1945 Gouzenko defection.

${ }^{25}$ King's ongoing exchanges about art with JDR Jr. included his unsuccessful attempt to convince British Prime Minister Attlee to transfer a series of colonial-era watercolours from the British Museum to Colonial Williamsburg. See file PREM 8/917, National Archives, London.

${ }^{26}$ See http://www.pc.gc.ca/lhn-nhs/on/laurier/index.aspx and http://www.canadascapital.gc.ca/bins/ncc web content page.asp?cid=16297-16299-10170-49685-4972149723\&lang=1 (Visited 12 November 2010)

${ }^{27}$ Mimmo Jodice, exhibit text, Musée Européenne de la photographie, Paris, May 2010. My translation.

${ }^{28}$ For a fascinating treatment of “sensorial urbanism” see Mirko Zardini, ed., The Sense of the City: An Alternate Approch to Urbanism, Montreal: Canadian Centre for Architecture, 2006.

${ }^{29}$ Giorgio Agamben, The Signature of All Things: On Method, Brooklyn, N.Y.: Zone Books, 2009, See chapter two, “Theory of Signatures,” 33-80.

${ }^{30}$ Ibid. Afterwards, JDR Jr. encouraged King in retirement to treat Williamsburg as a second home and sought King's aid in preparing his memoirs. King hoped to show Rockefeller his achievements in Ottawa, a visit hitherto precluded by the risk of King being seen too close to an American industrialist. In the event, King's health prohibited further visits one way or the other.

\section{Referências}

AGAMBEN, G. Homo Sacer: Sovereign Power and Bare Life, Stanford: Stanford University Press, 1998.

AGAMBEN, G. The Signature of All Things: On Method, Brooklyn, N.Y.: Zone Books, 2009, p.33-80.

BIANCA, S., Conservation of the Old City of Damascus, Paris: UNESCO, 1987.

BOLLAS C. The Evocative Object World, New York: Routledge, 2009.

DAUM A. W.; MAUCH C. (Eds). Berlin/Washington, New York: Cambridge University Press, 2005.

DUFFY, D. Love among the ruins: The King of Kingsmere, American Review of Canadian Studies. 2007, p.355-370.

GORDON D. William Lyon Mackenzie King, planning advocate. Planning Perspectives 2002.

GORDON, D. From noblesse oblige to nationalism: Elite involvement in planning Canada's capital, Journal of Urban History, Nov. 2001

GRÉBER, J. "Plan for the National Capital of Canada," Journal of the Royal Architectural Institute of Canada. 1949. 
GREENSPAN A. Creating Colonial Williamsburg: The Restoration of Virginia's Eighteenth Century Capital, Second Edition, Chapel Hill: University of North Carolina Press, 2009.

HETZLER, F. M. The Aesthetics of Ruins: A New Category of Being, Journal of Aesthetic Education 1982.

JODICE, M., exhibit text, Musée Européenne de la photographie, Paris, May 2010.

KNIGHT, D. Choosing Canada’s Capital: Conflict Resolution in a Parliamentary System, Ottawa: Carleton University Press, Journal of Urban History. 1991.

PARK, E. My Dream and My Hope. Colonial Williamsburg's. Disponível em:

http://www.history.org/foundation/general/introhis.cfm visited 12 November 2010.

PIANO, R. La désobéissance de l’Architecte, Arléa: Paris, 2009.

VIDAL, L., D’aeroplis à acropolis, les paraboles de Brasilia. In Brasilia : L'épanouissement d'une capitale, Paris: Éditions J. and A. Picard, 2006.

WHYTE,T. How buildings mean: some issues of interpretation in the history of architecture, History and Theory. 2006.

WILSTACH, P., Tidewater Virginia, New York: Blue Ribbon Books,1929.

WISE, M. Z. Capital Dilemma: Germany's Search for an Architecture of Democracy. New York: Princeton Architectural Press, 1998.

YETTER G. H. Williamsburg Before and After: The Rebirth of Virginia's Colonial Capital, Williamburg, Va.: The Colonial Williamsburg Foundation, 1996.

ZARDINI, Mirko (Ed.). The Sense of the City: An Alternate Approch to Urbanism, Montreal: Canadian Centre for Architecture, 2006.

Recebido em: 18/12/2010

Aprovado em: 27/02/2011 